\title{
HUKUM DAN KEADILAN: ISU BAGIAN HULU DAN HILIR
}

\author{
Titon Slamet Kurnia \\ Staf Pengajar Fakultas Hukum Universitas Kristen Satya Wacana \\ Korespondensi: titonslamet@gmail.com
}

\begin{abstract}
Abstrak
Hubungan antara hukum dan keadilan seperti aliran sungai yang mengalir dari hulu ke hilir. Sesuai analogi ini, keadilan adalah isu inheren dalam pembentukan undang-undang (isu bagian hulu) dan ajudikasi (isu bagian hilir). Konsisten dengan ini, penulis meyakini bahwa undang-undang dan ajudikasi harus adil karena presumsi bahwa keadilan adalah nilai internal hukum. Kita harus mewaspadai posisi bebas-nilai positivis karena mengarah pada pemikiran yang bersifat reduksionis tentang hukum. Untuk menanggapi isu tersebut penulis mendukung pendapat yang mengklaim bahwa kita tidak dapat memisahkan hukum dan keadilan. Kita mengacu hanya pada hukum hanya karena hukum tersebut adil.
\end{abstract}

Kata-kata Kunci: Hukum; Keadilan; Isu Bagian Hulu dan Hilir.

\begin{abstract}
The relationship between law and justice is analogous to a river. Like a river stream, justice flows from the upstream to the downstream in the legal discourse. According to this analogy, justice is inherent issue in the rule-making (the upstream issue) and adjudication (the downstream issue). Consistent with this statement the author believes that legislation and adjudication should be just because the presumption that justice is the internal value of the law. We should be aware that a value-free standpoint proposed by the positivist would lead us to a reductionist thinking about law. In order to address this issue, the author therefore argues for the unity thesis that claims that we cannot separate law and justice. We invoke only to the law because a conviction that the law is just.
\end{abstract}

Key Words: Law; Justice; Upstream and Downstream Issues. 


\section{PENDAHULUAN}

Undang-undang tidak sama dengan hukum. Filsafat hukum membedakan secara ontologis konsep hukum (dalam bahasa Latin disebut ius) dan undangundang (dalam bahasa Latin disebut lex). Undang-undang hanya salah satu sumber hukum dengan pengertian sebagai starting point dari hukum dalam menentukan perintah dan larangan yang otoritatif kepada subjek hukum. Karena pengaruh ajaran legal positivism maka perbedaan tersebut dalam perkembangannya terdisorientasi dan dianggap tidak penting lagi sehingga tesis yang lebih dominan yaitu "Hukum adalah Undang-undang." Positivis menjustifikasi pendiriannya dengan argumen bahwa kekuasaan negara memvalidasi undang-undang. ${ }^{1}$ Oleh karena itu hukum kemudian menjadi identik dengan kekuasaan.

Tulisan ini tetap mempertahankan perbedaan antara konsep hukum dan konsep undang-undang sebagai isu yang relevan dalam mendiskusikan hubungan antara hukum dan keadilan. Tulisan ini akan mendiskusikan hubungan antara hukum dan keadilan dengan menggunakan analogi aliran sungai, bagian hulu (upstream) dan bagian hilir (downstream). Sebagai salah satu sumbernya, undang-undang harus mengandung ciri kodrati hukum, yaitu keadilan. Oleh karena itu tugas pembentuk undang-undang adalah merumuskan undang-undang yang adil. Hal ini adalah isu bagian hulu, bagian awal, dalam diskusi tentang hubungan antara hukum dan keadilan.

Legal reasoning merupakan segi praktis dari ilmu hukum. Legal reasoning adalah aktivitas untuk menjustifikasi putusan atau tindakan yang diambil atas suatu isu hukum supaya tidak terjadi kesewenangwenangan mengenai putusan atau tindakan yang diambil. ${ }^{2}$ Aktivitas melakukan legal reasoning tidak dapat diisolir dari konsep keadilan kecuali secara presumtif diyakini bahwa keadilan telah inheren dalam undangundang. Dalam situasi demikian, setiap legal reasoning secara otomatis adil jika undang-undangnya sendiri adil secara inheren. Ketidakmampuan pembentuk undang-undang untuk menghasilkan undang-undang yang adil harus dikompensasi dengan penerapannya pada kasus-kasus individual-konkret melalui legal reasoning yang menampung muatan keadilan. Hal ini adalah isu bagian hilir dalam diskusi tentang hubungan antara hukum dan keadilan.

Tesis penulis sebagai dasar dalam pembahasan terhadap kedua isu tersebut adalah undang-undang dan legal reasoning merupakan elemen esensial hukum sehingga keduanya harus mengandung kualitas keadilan sebagai nilai internalnya. Sistematika

Pendapat Gustav Radbruch dalam Heather Leawoods, 'Gustav Radbruch: An Extraordinary Legal Philosopher' (2000) 2 Washington University Journal of Law and Policy 489, 497-498.

Bandingkan Altman: "Legal reasoning proceeds on the assumption that authoritative decisions that make up the law are not arbitrary: there are reasons for the decisions." Andrew Altman, Arguing About Law (Wadsworth Publishing Co. 2001) 289. 
pembahasan tulisan ini terdiri dari dua bagian. Bagian pertama akan menjelaskan isu bagian hulu dalam hubungan antara hukum dan keadilan, yaitu konsep ontologis undang-undang yang adil. Dengan pengertian lain secara konseptual fokus pembahasan ini adalah tentang legislasi. Bagian kedua akan menjelaskan isu bagian hilir, yaitu legal reasoning yang bermuatan keadilan dalam situasi kegagalan pembentuk undang-undang untuk menghasilkan undang-undang yang adil, sesuai cita hukumnya. Fokus pembahasan ini adalah tentang ajudikasi. Pada bagian ini penulis akan merujuk pandangan sarjana berpengaruh yaitu Radbruch.

\section{PEMBAHASAN}

\section{Isu Bagian Hulu: Keadilan Sebagai Jiwa Undang-Undang}

Pembahasan tentang keadilan sebagai landasan normativitas undangundang bertolak dari konsep hukum tertentu. Yang dimaksud dengan konsep hukum di sini adalah hakikat atau esensi hukum sebagaimana diyakini atau dipegang oleh seseorang sebagai praktisi hukum. Untuk lebih memudahkan dalam pemahaman, penulis menggunakan pendekatan dikotomis tentang hakikat hukum, dengan mengacu pada Robert Alexy, yaitu konsep yang positivistik dan konsep yang non-positivistik. Tentang konsep hukum yang positivistik Alexy menyatakan: "there are only two defining elements: that of issuance in accordance with the system, or authoritative issuance, and that of social efficacy ... Common to all of the variations is the notion that what law is depends solely on what has been issued and/or is efficacious. Correctness of content-however achieved - counts for nothing."3 Sementara kebalikannya, konsep hukum yang non-positivistik:

defend the connection thesis, which says that the concept of law is to be defined such that moral elements are included. No serious non-positivist is thereby excluding from the concept of law either the element of authoritative issuance or the element of social efficacy. Rather, what distinguishes the non-positivist from the positivist is the view that the concept of law is to be defined such that, alongside these fact-oriented properties, moral elements are also included. ${ }^{4}$

Konsep hukum yang positivistik sering pula disebut dengan istilah separation thesis karena membedakan hukum yang ada (hukum positif) dengan hukum yang seharusnya atau yang ideal (law as it is dengan law as it ought to be). Konsep hukum yang non-positivistik sebaliknya, disebut dengan istilah unity thesis.

Perdebatan antar kedua pendirian tersebut sudah bersifat klasik dalam studi jurisprudence. ${ }^{5}$ Atas isu tersebut penulis memilih posisi ketidakniscayaan separation thesis (pandangan value free terhadap hukum). Fuller misalnya mengingatkan: "The respect we owe to human laws must surely be something different from the respect we accord to the law of gravitation." 6 Luis Recaséns

Robert Alexy, The Argument from Injustice: A Reply to Legal Positivism (Oxford University Press 2004) 3-4.

Ibid., 4. 
Siches, filsuf hukum Amerika Latin, menyatakan: "Every idea of ought-to-be, of normativity, is based on judgment, that is, on an appreciation of values."

Pendirian non-positivistik juga nampak dalam diri Radbruch: "Law is a creation of man, and like any human creation it can be understood only by its idea... a view of human creations that is blind to purposes, that is, to values, is impossible." 8 Pengertian tersebut dipertahankan oleh Radbruch dengan tesis bahwa hukum adalah fenomena budaya, fakta yang terkait dengan nilai, sehingga hukum mengandung secara inheren cita hukum (the idea of law): "Law is a cultural phenomenon, that is, a fact related to value. The concept of law can be determined only as something given, the meaning of which is to realize the idea of law. Law may be unjust (summum jus - summa injuria); but it is law only because its meaning is to be

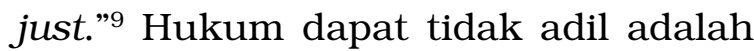
pernyataan deskriptif/faktual; akan tetapi, baru disebut hukum hanya jika adil adalah pernyataan normatifnya. Oleh karena itu Radbruch lantas memposisikan keadilan a priori terhadap hukum lewat maxim-nya: "est autemjus a justitia, sicut a matre sua, ergo prius fuit justitia quam jus (but law issues from justice as from its mother, as it were, so there has been justice prior to law)." 10

Bentuk moderat pendirian nonpositivistik adalah inclusive legal positivism. Menurut Waluchow:

A distinguishing feature of inclusive positivism is its claim that standards of political morality, that is, the morality we use to evaluate, justify, and critize social institutions and their activities and products, e.g. laws, can and do in various ways figure in attempts to determine the existence, content, and meaning of valid laws. Political morality, on this theory, is included within the possible grounds for establishing the existence and content of valid, positive laws, that is, laws enacted or developed by human beings in legislatures, courts of law, or customary practice. ${ }^{11}$

Pendekatan ini, tidak seperti pendekatan legal positivism pada umumnya (yaitu yang memisahkan secara tegas antara hukum dan moral atau separation thesis), menerima kemungkinan peran moralitas sebagai standar evaluasi dan kritisisme hukum positif (undangundang), termasuk menentukan materi muatannya yang ideal.

Pendirian penulis dikatagorikan sebagai inclusive legal positivism karena tetap memperlakukan hukum positif yaitu undang-undang (aspek formal)

$5 \quad$ Misalnya perdebatan H.L.A. Hart, 'Positivism and the Separation of Law and Morals' (1958) 71 Harvard Law Review 593 dan Lon L. Fuller,'Positivism and Fidelity to Law-A Reply to Professor Hart' (1958) 71 Harvard Law Review 630.

$6 \quad$ Lon L. Fuller, Ibid., 632.

7 Edgar Bodenheimer, Jurisprudence: The Philosophy and Method of the Law (Harvard University Press 1970) 39.

$8 \quad$ Kurt Wilk, The Legal Philosophy of Lask, Radbruch and Dabin (Harvard University Press 1950) 51-52.

Ibid., 52.

Ibid., 73.

W.J. Waluchow, Inclusive Legal Positivism (Oxford University Press 1994) 2-3. 
sebagai starting point. Sementara keadilan atau moralitas (aspek substantif) berfungsi sebagai kriteria evaluatifnya. Argumen ini didasari pemikiran, dengan cakupan lebih luas yaitu hukum pada umumnya, bahwa di samping memerlukan the force of law, juga pada saat yang sama the grounds of law tidak terelakkan untuk menjustifikasi keberlakuan hukum yang pelanggaran kepadanya melegitimasi State coercion (dalam hal ini the force of law). ${ }^{12}$

Implikasi dari konsep hukum yang non-positivistik adalah tesis bahwa undang-undang harus adil. Alasan penolakan penulis terhadap konsep hukum yang positivistik adalah karena pendiriannya yang bebas nilai atau secara moral netral, melakukan pemisahan antara hukum (materi muatannya) dengan nilai atau moral. Sebagai contoh pernyataan Kelsen berikut ini: "Any content whatsoever can be legal." 13 Pendirian value free berpotensi menimbulkan dampak negatif, terlebih menempatkan kekuasaan sebagai the ultimate answer atas pertanyaan tentang validitas dan kekuatan mengikat dari hukum kepada subjek hukum. Misalnya pendirian the command theory of law yang dipertahankan oleh Bentham dan Austin dengan tesisnya: "law as the command of a sovereign backed by a sanction." ${ }^{14}$ Segala hal yang tidak bermoral dapat mengikat sebagai hukum sepanjang secara formal telah memenuhi kriteria validitas, misalnya dibentuk oleh badan atau pejabat negara yang berwenang (kasus Nuremberg Race Laws).

\section{Undang-undang harus adil.} Validitasnya tidak cukup hanya bergantung pada kekuasaan negara dalam pengundangannya serta dalam penegakannya. Tanpa elemen keadilan maka undang-undang sangat sulit dibedakan dari 'premanisme' (gunman's threat). Tanpa keadilan maka undangundang tidak layak menyandang predikat sebagai hukum. Inoue mengemukakan konsep hukum yang dinamakannya dengan 'the concept of law as a project for justice' dalam menjelaskan tuntutan mengapa undang-undang harus adil:

Normative statements are distinguished from imperatives by involving not just a demand for obedience but a claim that there are reasons that justify their demand. As a normative system law involves a claim to reason-based justifiability. The differentia specifica that

12 W.J. Waluchow, Ibid., 9. Perbedaan antara the force of law dan the grounds of law dikemukakan oleh Dworkin. Grounds of law adalah "circumstances in which particular propositions of law should be taken to be sound or true." Ibid., 9. Force of law adalah "the relative power of any true proposition of law to justify coercion in different sorts of exceptional circumstances." Ibid., 12. Waluchow menjelaskan posisi Dworkin tentang hubungan antara the grounds of law dan the force of law sebagai berikut: jika the grounds of law nampak asing secara moral maka implikasinya adalah kesulitan menemukan, bahkan non-eksistensi, the force of law, yaitu the law's power to justify coercion atas pelanggaran. Contoh: undang-undang dengan dasar supremasi rasial. Undang-undang demikian tidak dapat dipaksakan keberlakuannya karena secara moral tidak dapat dibenarkan. Ibid.

13 Edgar Bodenheimer, Op.Cit., 176-177.

14 Hilaire Mc Coubrey \& Nigel D. White, Textbook on Jurisprudence (Blackstone Press Ltd. 1996) 13-24. 
distinguishes law from other species of norms is that the justificatory reasons it claims to have are reasons based on justice as a distinct value, distinct from love, spiritual salvation and the like. Law claims that it is in accordance with justice. This justice-claim inheres in the concept of law. The gunman's threat is not only unjust. Being a pure imperative, it does not even need to claim to be just. ${ }^{15}$

Pertanyaannya adalah: Apakah kriteria bagi undang-undang yang adil? Jawaban atas pertanyaan ini dikemukakan oleh Bodenheimer: "From the point of view of justice, we are deeply interested in the fairness and reasonableness of these rules, principles, and standards, their effects upon human beings, and their worth as measured in terms of their contribution to human happines and productive human effort." 16 Ada tiga pengertian keadilan dalam pendapat Bodenheimer tersebut. Pertama, fairness dan reasonableness undang-undang yang ditujukan pada rules, principles, and standards yang tertuang dalam ketentuanketentuannya. Fairness menyangkut soal-soal prosedural atau cara, sementara reasonableness menyangkut soal-soal substantif atau materi muatannya. Kedua, akibat yang ditimbulkan kepada umat manusia. Akibat di sini mengacu pada tuntutan yang bersifat positif berkenaan dengan integritas atau keutuhan manusia (tidak boleh melanggar secara terang-terangan integritas atau keutuhan manusia). Ketiga, kontribusinya pada kebahagiaan manusia dan upaya produktif manusia.
Kontribusi di sini juga mengandung pengertian kontribusi positif bahwa undnag-undang harus membahagiakan manusia dan harus memajukan upaya produktif manusia; bukan sebaliknya, memberikan nestapa kepada manusia tanpa justifikasi yang jelas dan masuk akal. Lebih lanjut Bodenheimer mengemukakan proyeksi bagi pemikiran tentang undang-undang yang adil sebagai berikut:

A social order striving to be just must also grant to men certain other basic rights which may be regarded as aspects of freedom in a larger sense. Among these may be counted the right to life, the right to the security of the person, and the right to own property, together with the necessary legal implementation of these rights ... Thus the legal order must provide redress for invasions of the integrity of the person, must restore wrongfully taken property to its owners, and compensate men for other loses which they have suffered through unlawful acts. Without corrective justice, i.e., the defense of the system of rights and duties established by distributive justice, the latter would be ineffective. ${ }^{17}$

Dalam kriteria Dworkin, undangundang yang adil seharusnya 'take rights seriously'. Taking rights seriously menurut Dworkin adalah sebuah starting point yang sangat fundamental sebagai tuntutan kepada pemerintah untuk memberikan equal respect and concern kepada warganya. Dworkin menyatakan pemikirannya tersebut:

Anyone who professes to take rights seriously, and who praises our Government for respecting them, must

\footnotetext{
15 Tatsuo Inoue, The Rule of Law as the Law of Legislation dalam Luc J. Wintgens ed., Legislation in Context: Essays in Legisprudence (Ashgate 2007) 65.

16 Edgar Bodenheimer, Op.Cit., 177.

17 Ibid., 205.
} 
have some sense of what that point is. He must accept, at the minimum, one or both of two important ideas. The first is the vague but powerful idea of human dignity. This idea is associated with Kant, but defended by philosophers of different schools, supposes that there are ways of treating a man that are consistent with recognising him as a full member of the human community, and holds that such treatment is profoundly unjust. The second is the more familiar idea of political equality. This supposes that the weaker members of a political community are entitled to the same concern and respect of their government as the more powerful members have secured for themselves, so that if some men have freedom of decision whatever the effect on the general good, then all men must have the same freedom. ${ }^{18}$

Pemikiran tersebut menurut hemat penulis berlaku pula sebagai asas substantif dalam legislasi. Proses legislasi yang konsisten dengan asas tersebut akan menghasilkan undangundang yang adil ala Dworkin.

Isu-isu mengenai ketidakadilan undang-undang lazimnya diangkat dengan bertolak dari kegagalan pembentuk undang-undang dalam merealisasikan gagasan equality dan freedom. Salah satu contoh adalah Undang-undang Nazi yang sering dijadikan sebagai rujukan untuk menunjukkan undang-undang yang materi muatannya tidak adil.

McCoubrey \& White berkomentar:

Nazi law to a very significant extent not only failed to respect, but was precisely calculated to deny, their status as participating members of a human society. This might be differently expressed as a conclusion that law and its administration in the Third Reich to a considerable extent contravened the Kantian categorical imperative and principle of right. It will be recalled that these respectively argue that any maxim for particular should be capable of being used as a general maxim and that humanity should always be respected as an end in itself and not treated as a means to some other end. ${ }^{19}$

Contoh lebih eksplisit adalah judicial opinion Lord Cross of Chelsea dalam kasus Oppenheimer v. Cattermole (1976) yang diajukan ke hadapan the House of Lords. Dalam kasus tersebut Lord Cross of Chelsea menyatakan: “... legislation which takes away without compensation from a section of the citizen body single out on racial grounds all their property ... and ... deprives them of their citizenship ... constitutes so grave an infringement of their human rights that the courts of this country ought to recognise it as a law at all." 20

Dalam rangka keadilan, undangundang dituntut harus mampu menjembatani nilai-nilai individu dan sekaligus nilai-nilai komunitas (konsep keadilan sebagai common good). Hal ini sangat penting karena individu selalu hidup bersama-sama dengan sesamanya, dan sampai kapanpun tidak mungkin hidup secara terisolir. Menjembatani nilai-nilai tersebut sangat penting agar tidak ada yang saling dikorbankan kepentingannya. Dalam konteks ini Bodenheimer memajukan tesis:"Justice requires some accomodation and synthesis between

\footnotetext{
18 Ronald Dworkin, Taking Rights Seriously (Harvard University Press 1978) 198-199.

19 Hilaire McCoubrey \& Nigel D. White, Op.Cit., 286.

$20 \quad$ Ibid., 283.
} 
individual and community values." Tesis ini bertolak dari pemikiran bahwa:"the notions of liberty, equality and fundamental rights are not entirely sufficient to explain and determine the idea of justice." Sehingga Bodenheimer kemudian sampai pada satu formulasi yaitu: "Justice demands that freedom, equality, and other basic rights be accorded and secured to human beings to the greatest extent consistent with the common good." ${ }^{21}$

Konsepsi keadilan sebagai common good ini nampak dalam karya Edmond Cahn berjudul The Sense of Injustice. Cahn memberikan perhatian serius pada tuntutan kepada sistem hukum dalam rangka to responds to new moral convictions and new social needs. Kegagalan memberikan respons tersebut adalah praktik injustice: "Thus, the positive law may become unjust not only by breaking its promise of regularity and consistency, but also by violating its commitment to be sensitive to new demands of the social ad economic life." 22 Dalam pada itu, yang menjadi kesulitan adalah mendefinisikan konsep common good yang objektif pengertiannya. Gagasan yang dijadikan sebagai acuan atau rujukan guna mendefinisikan konsep common good adalah civilization atau peradaban dan peranan manusia dalam memberikan kontribusi sebesarbesarnya dalam rangka pembangunan sebuah peradaban. Dalam pengertian demikian maka hal itu hanya mungkin terjadi manakala manusia diajarkan untuk berwatak dan bersikap "selfinterest by self-restriction in the interest of others, to respect the dignity of fellow men, and to devise proper rules for coexistence and cooperation on the various levels of group life, including the international community." 23

Pokok pikiran dari diskusi di atas adalah tentang hakikat keadilan sebagai konsepsi ideal yang seyogianya diakomodasi oleh pembentuk undangundang ketika tengah membentuk suatu undang-undang. Merealisasikan idealideal tersebut agar menjadi ketentuanketentuan undang-undang yang bersifat dan berlaku umum bukan hal yang mudah karena prosesnya yang politis. Oleh karena itu, meskipun hasil akhirnya tidak mampu ideal, namun karena isu ini berada di bagian hulu, maka masih terbuka kemungkinan untuk melakukan koreksi. Ajudikasi adalah benteng terakhir keadilan, yang fungsinya dalam rangka keadilan, salah satunya adalah mengkoreksi produk undang-undang yang tidak adil melalui legal reasoning yang harus bermuatan keadilan. Oleh karena itu penulis sampai pada satu pemikiran bahwa memutus menurut undang-undang dengan memutus menurut hukum tidak selalu identik maknanya. Dalam memutus menurut hukum hakim harus memberikan legal reasoning yang adil, termasuk mengesampingkan undangundang yang tidak adil. Oleh karena itu, legal reasoning yang adil bukan merupakan penerapan mekanis undang-

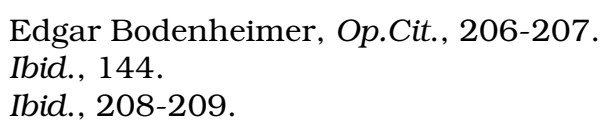


undang (kecuali undang-undangnya sendiri telah adil secara inheren).

\section{Isu Bagian Hilir: Legal Reasoning Bermuatan Keadilan}

Makna atau hakikat hukum dalam fungsi hakim adalah isu teoretis sangat penting dalam rangka ajudikasi. Isu ini merupakan salah satu bidang kajian filsafat hukum (dalam hal ini metateori interpretasi), maupun teori hukum yang lebih konkret (dalam hal ini teori interpretasi itu sendiri). Dipengaruhi oleh aliran atau tradisi filsafat hukum tertentu atas makna atau hakikat hukum, metateori interpretasi yang ada telah lazim dikatagorikan menjadi teori formalisme, teori realisme dan teori normativisme.

Teori-teori tersebut pada hakikatnya merupakan bentuk penerapan aliran filsafat hukum tertentu ke dalam ajudikasi sehingga konsekuensinya lebih dikenal dengan predikat teori ajudikasi, yaitu: "theories of how judges do or should decide cases." ${ }^{4}$ Atau lebih tepatnya tentang: "how should a judge decide what law governs the case before her?"25 Dalam arti demikian maka yang menjadi fokus teori-teori tersebut adalah judicial reasoning sebagai spesies dari legal reasoning. Teori-teori tersebut sangat penting dalam rangka fungsionalitas badan yudisial dan hakim, terutama hakikat fungsi hakim dan makna atau hakikat hukum di dalamnya.

Thomas menyatakan: "a basic understanding of legal theory is essential for the complete performance of the judicial function ... To fulfil their judicial function, and to be able to assess whether they are fulfilling that function, judges must explore, examine and know the theoretical framework for their judicial thinking." ${ }^{26}$ Pernyataan ini sangat tepat sasaran manakala diyakini bahwa ajudikasi dan interpretasi adalah aktivitas intelektual yang sophisticated. Thomas menjelaskan hal ini dengan cara melakukan perbandingan antara fungsi hakim dengan plumber: "Plumbers may plumb for a lifetime without perplexing themselves as to what their trade is all about. But the administration of justice in accordance with the law is far removed from plumbing. A judge cannot simply judge as a plumber may plumb." ${ }^{27}$

Formalisme, realisme dan normativisme pada hakikatnya adalah teori tentang makna atau hakikat hukum dalam ajudikasi, yang mengandung dimensi penerapan atas

24 Brian Leiter, 'Legal Formalism and Legal Realism: What is the Issue?' (2010) 16 Legal Theory $111,111$.

25 Robert Justin Lipkin, 'Conventionalism, Pragmatism and Constitutional Revolutions' (1988) 21 UC Davis Law Review 645, 651.

26 E.W. Thomas, The Judicial Process: Realism, Pragmatism, Practical Reasoning and Principles, (Cambridge University Press 2005) 1. Bdgk. dengan Aharon Barak, The Judge in a Democracy (Princeton University Press 2006) 116-117. Barak mengklaim aspek aksiologis teori adalah "to understand the law and the role of the judge." Oleh karena itu Barak menyimpulkan: "Judges need theories of law, and theories of law need judges." Pendapat Barak menunjukkan bahwa filsafat hukum dan teori hukum adalah praktikal (untuk menunjang kepentingan praktik hukum).

27 E.W. Thomas, Ibid. 
studi filsafat hukum, yang bertujuan menghasilkan postulat-postulat mengenai makna atau hakikat hukum sebagai pendirian, world view, bagi hakim ketika melakukan ajudikasi, tentang bagaimana hakim memutus atau seyogianya memutus kasus dalam lingkup tugas yudisialnya. Segi filosofis dari ajudikasi ini nampak dari pendapat D'Amato: "the way judges decide a case is informed by their own conceptions of what the law is-not just what a statute might say, or a previous case might have held, but what the law is in the sense of how they should interpret those statutes or cases." 28 Aliran atau tradisi filsafat hukum tertentu membentuk dan menentukan makna atau hakikat hukum tertentu, dan yang pada analisis akhir menentukan hakim tentang bagaimana mengembannya ketika memeriksa, mengadili dan memutuskan kasus.

Sesuai dengan konsep hukum yang menjadi pendirian penulis maka selanjutnya penulis akan menjelaskan teori legal reasoning yang bertolak dari konsep hukum non-positivistik, yaitu teori normativisme (dalam bentuk lebih moderat disebut inclusive legal positivism). Bentuk argumen yang lazim digunakan oleh normativis dalam legal reasoning adalah argumen normatif, yaitu "the realm of judgments that reflect moral evaluations, or evaluations like moral judgments." ${ }^{29}$ Hal ini berbeda dengan bentuk argumen yang digunakan positivis yaitu argumen deskriptif dan netral secara moral. Marmor mengatakan:

I will argue that legal positivism is best understood as a descriptive, morally neutral, theory about the nature of law, along the lines suggested by H.L.A. Hart. By "descriptive" I mean that such an account does not purport to justify or legitimize any aspect of its subject matter. By "morally neutral," I mean that the theory need not take a stance on any particular moral or political issues, nor is it committed to any moral or political evaluations. ${ }^{30}$

Esensi khas legal reasoning menurut perspektif teori normativisme adalah lebih dari sekadar penerapan mekanis undang-undang (formalisme) serta lebih dari memutus dengan pertimbangan social demands(realisme). Teori normativisme memiliki aspirasi kuat terhadap legal reasoning supaya mempresentasikan argumen-argumen justifikasi lebih fundamental dan substantif. Singer menyatakan: "We have trouble finishing the 'because clause'; reasons run out." ${ }^{31}$ Teori normativisme memiliki tujuan menjawab pertanyaan "why" yang acapkali diabaikan atau dipandang skeptis dalam situasi argumentatif. Singer menyatakan:

\footnotetext{
28 Anthony D’Amato, Analytic Jurisprudence Anthology (Anderson Publishing Co. 1995) 1. Pendapat senada dikemukakan oleh MacCormick: "theories about the nature of law can be tested out in terms of their implications in relation to legal reasoning." Neil MacCormick, Legal Reasoning and Legal Theory, (Clarendon Press 1978) 229.

29 Andrei Marmor, Law in the Age of Pluralism (Oxford University Press, 2007) 126.

$30 \quad$ Ibid., 125.

$31 \quad$ Joseph William Singer, 'Normative Methods for Lawyer' (2009) 56 UCLA Law Review 899, 903.
} 
When asked to defend our views, we can come up with reasons, but we know that our arguments can always be met with the question "why?" and we are acutely aware that, at some point, we will have nothing else to say. What is the foundation of assertions of justice, morality, right, and fairness? Why is a claim of justice anything more than a personal opinion? Is it possible to reason about justice? ${ }^{32}$

Dalam diskursus yuridis, argumen fundamental dan substantif sangat penting khususnya ketika menghadapi hard cases: "What can be said to the losing party to a lawsuit that is not just a transparent attempt to dupe her into accepting a painful loss?"33

\section{Singer mengemukakan tentang} makna strategis argumen normatif sebagai berikut:

Normative arguments express evaluative judgments about why certain values outweigh other values in particular contexts. The goal is to show respect for all persons affected by the dispute. Although there may not be a unique, mechanically derivable right answer, the decisionmaker is still obligated to come up with her best formulation of the right answer that treats the loser with equal concern and respect. ${ }^{34}$

Ibid.

Ibid., 910.

Ibid., 981.

Ibid., 982.

Ibid., 914.

Ibid., 913-921.

Singer mengemukakan kritiknya: "Many legal rules are indeterminate without reference to considerations of morality and justice." Ibid., 914.

39 Singer mengemukakan kritiknya sebagai berikut: "Most human values cannot be expressed adequately in numerical (especially dollar) amounts." Ibid., 919. Lalu, "Indeed, when a question involves interpretation of human values, mathematics is ordinarily an irrational way to think about the matter." Ibid., 921.

$40 \quad$ Singer mengemukakan kritiknya: "Cost-benefit analysis suffers from the limitations of all utilitarian reasoning; it fails to respect the separateness of persons because it assumes that the gains of some can fully offset the loses of others." Ibid., 928.
Dalam arti demikian maka tujuan akhir argumen normatif dari teori normativisme adalah kemanusiaan:

At base, the fundamental premise of all normative method is humanity. Human dignity is where we start, and defensible human relationships are our goal ... Although our respective goals can be phrased in different ways, a good candidate is the creation of a free and democratic society that treats each person with equal concern and respect. ${ }^{35}$

Normativisme berbeda dengan formalisme menyangkut isu hubungan antara hukum dengan moral: "although we do separate law and morals, we do not separate them entirely." 36 Normativisme juga berbeda dengan realisme, walau sama-sama bertolak dari tesis indeterminate legal rules. Normativisme lebih berorientasi pada realisme kebalikannya, lebih berorientasi pada fakta (wealth maximization, efficiency, cost-benefit). ${ }^{37}$ Normativisme lahir sebagai kritik terhadap formalisme maupun realisme. Formalisme dikritik karena pendirian bebas nilainya. ${ }^{38}$ Sementara realisme dikritik karena kecenderungan matematis ${ }^{39}$ dan pragmatismenya $^{40}$. nilai (morality, justice, fairness); namun 
Bentuk preskripsi paling kuat atas isu hubungan antara keadilan dan undang-undang dalam praksis legal reasoning adalah penerapannya seperti formula hukum kodrat St. Augustine "lex iniusta non est lex". Formula ini menurut Ratnapala mengandung pengertian: "at some point on the moral scale an enactment may be seen as so immoral or unjust that it loses its authority as law."Argumen ini dipopulerkan oleh Radbruch dalam memberikan judgment terhadap keberlakuan undang-undang Nazi di Jerman. ${ }^{41}$ Pandangan Radbruch dimaksud adalah tulisannya berjudul "Five Minutes of Legal Philosophy" (salah satu tulisan dalam Philosophy of Law dengan editor Joel Feinberg \& Hyman Gross, 1991) serta "Statutory Non-Law and Suprastatutory Law" (hasil terjemahan ke dalam bahasa Inggris oleh Bonnie Litschewski Paulson \& Stanley L. Paulson, 1993) yang merupakan karya Pasca Perang Dunia II. ${ }^{42}$

Filsafat hukum Radbruch dapat digambarkan sebagai produk pemikiran yang dinamis dalam dua pengertian. Pertama, tidak mengikatkan diri ke dalam salah satu mazhab filsafat hukum tradisional, tetapi mengkombinasikan secara dialektik; ${ }^{43}$ di sini penulis berpendapat bahwa lebih tepat jika normativisme Radbruch masuk katagori inclusive legal positivism. Kedua, Radbruch tidak anti untuk merevisi pandangan-pandangannya (sebelum
Perang Dunia II dan pasca Perang Dunia II). ${ }^{44}$

Sebagai survivor dari pemerintahan Nazi-Jerman selama 12 tahun, Radbruch menyatakan rasa tidak puasnya atas pendirian legal positivism sebagai berikut:

Legal positivism, with its principle that 'a law is a law,' has in fact rendered the German legal profession defenseless against statutes that are arbitrary and criminal. Legal positivism is, moreover, in and of itself wholly incapable of justifying or explaining the validity of statutes. The positivist believes he [she] has proved the validity of a statute simply by showing that it had sufficient power behind it to prevail. But although compulsion may be based on power, obligation and validity never are. Obligation and validity must be based, rather, on a value that inheres in the statute. ${ }^{45}$

Ketidakpuasan Radbruch terhadap pendirian legal positivism dimotivasi oleh praktik penyalahgunaan hukum positif oleh rezim Nazi-Jerman. Hal ini berpengaruh besar terhadap pandangan Radbruch atas ajaran filsafat hukumnya terdahulu yang lebih bernuansa positivisme, yaitu memberi pengutamaan pada kepastian hukum. Pasca Perang Dunia II Radbruch lalu merumuskan sintesis ajaran filsafat hukumnya sebagai koreksi terhadap pendiriannya terdahulu dengan cara membedakan situasi keberlakuan hukum, yaitu situasi biasa (ordinary times) dan situasi luar biasa

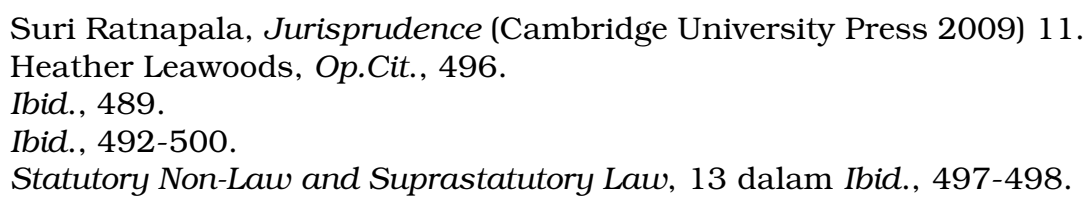


(extraordinary times). Dalam situasi biasa, kepastian hukum menjadi keutamaan; dalam situasi luar biasa, keadilan yang harus diutamakan. Radbruch menyatakan dua formula bagi dua situasi tersebut berikut ini:

Preference is given to the positive law, duly enacted and secured by State power as it is, even when it is unjust and fails to benefit the people, unless its conflict with justice reaches so intolerable a level that the statute becomes, in effect, 'false law' and must therefore yield to justice ... Where there is not even an attempt at justice, where equality, the core ofjustice, is deliberately betrayed in the issuance of positive law, then the statute is not merely 'false law', it lacks completely the very nature of law. For law, including positive law, cannot be otherwise defined than as a system and an institution whose very meaning is to serve justice. ${ }^{46}$

Karena pernyataan tersebut maka wajar jika kemudian dikatakan bahwa Radbruch adalah praktisi kontemporer ajaran St. Augustine.

Pada analisis akhir Radbruch percaya bahwa letak dari tuntutan normativitas terhadap hukum positif yang sesungguhnya adalah pada HAM, terutama sebagai respons terhadap para tiran yang bertindak menyalahgunakan kekuasaannya dalam membentuk hukum positif. Radbruch mengatakan: "We appeal to human rights that surpass all written laws, and we appeal to the inalienable, immemorial law that denies validity to the dictates of inhuman tyrants." 47 Serta, pada kesempatan berbeda:
There are, therefore, principles of law that are stronger than any statute, so that a law conflicting with these principles is devoid of validity. One calls these principles the natural law or the law of reason. To be sure, their details remain somewhat doubtful, but the work of centuries has established a solid core of them and they have come to enjoy such a far-reaching consensus in the declarations of human and civil rights that only the deliberate skeptic can still entertain doubts about some of them. ${ }^{48}$

Lewat dua pernyataan di atas pendirian natural law Radbruch sebagai antitesis pendirian positivisme-nya sebelum Perang Dunia II telah dikonversi menjadi tuntutan lebih konkret, yaitu HAM merupakan dasar tuntutan normativitas terhadap hukum positif.

Dengan mengacu pendapat di atas, hakim dapat secara sah menyisihkan undang-undang jika penerapan undangundang dalam kasus berdampak menimbulkan ketidakadilan. Ini berbeda dengan pendirian Dworkin yang mengemas sedemikian rupa interpretasi hukum positif oleh hakim agar dapat memancarkan makna keadilan sebagai moralitas hukum. Pendirian Radbruch lebih spesifik keberlakuannya, yaitu situasi abnormal manakala undangundang secara internal terlahir tidak adil sehingga atas dasar itu hakim dapat menyatakan undang-undang demikian tidak memiliki validitas (statutory nonlaw karena keberlakuan suprastatutory law yaitu keadilan) supaya tidak sekadar menjadi corong undang-undang. Argumen Radbruch sangat penting

Statutory Non-Law and Suprastatutory Law, 14-15 dalam Ibid., 500. Statutory Non-Law and Suprastatutory Law, 10 dalam Ibid., 497. Five Minutes of Legal Philosophy dalam Ibid., 496. 
implikasinya bagi institusi dan praktik pengujian yudisial konstitusionalitas undang-undang yang di Indonesia diemban oleh Mahkamah Konstitusi (dan terbukti bahwa di Mahkamah Konstitusi Jerman pendapat Radbruch tersebut sangat berpengaruh).

The Federal Constitutional Court Jerman dalam kasus konstitusionalitas penerapan undang-undang kewarganegaraan masa pemerintahan Nazi (BVerFGE 23 [1968]) menyatakan legal reasoning putusannya:

Law and justice are not left to the discretion of the lawmaker. The idea that a 'constitutional framer can arrange everything as he pleases would mean reverting to a mental posture of value-free statutory positivism that has long since been obsolete in legal science and practice. Precisely the period of the National Socialist regime in Germany has taught that lawlessness [Unrecht] can issue even from the lawmaker.' Therefore, the Federal Constitutional Court has affirmed the possibility of revoking the legal validity of National Socialist 'legal' provisions when they conflict with fundamental principles of justice so evidently that the judge who elected to apply them or to acknowledge their legal consequences would be administering lawlessness [Unrecht] rather than law. Ordinance 11 violated these fundamental principles. Its conflict with justice reached such an intolerable degree that the Ordinance must be held to be null and void, that is, invalid from the outset. Moreover, the Ordinance did not become efficacious in virtue of having been observed a number years or because some persons subject to 'denaturalization' had at the time come to terms or even concurred with National Socialist measures in particular cases. Duly enacted lawlessness that is obviously in violation of the constituting principles of the law does not become law in virtue of having been applied and obeyed. ${ }^{49}$

Duduk perkara kasus ini tentang seorang pengacara yang kehilangan kewarganegaraan Jerman-nya karena keberlakuan Ordinance 11 sebagai peraturan pelaksanaan the Statute on Reich Citizenship. Tesis legal reasoning dari the Federal Constitutional Court Jerman adalah undang-undang kewarganegaraan Jerman pada masa Nazi bukan hukum karena undangundang ini tidak adil, bertentangan dengan prinsip konstitutif hukum yaitu keadilan, meskipun pada masa berkuasanya Nazi undang-undang ini efektif dengan dipatuhi dan diterapkan secara konsisten oleh rezim tersebut.

\section{PENUTUP}

Keadilan adalah moralitas internal hukum menurut konsep hukum nonpositivistik atau unity thesis. Implikasi dari pandangan ini adalah undangundang maupun legal reasoning harus bermuatan keadilan. Proses legislasi yang menghasilkan undang-undang tidak adil harus dikoreksi oleh proses ajudikasi dengan memberikan legal reasoning yang bermuatan keadilan.

Berdasarkan teori normativisme, keadilan adalah bagian inheren dari legal reasoning. Menurut teori ini, legal reasoning bukan penerapan mekanis undang-undang (rules-based reasoning). Dalam bentuknya yang terkuat, dengan argumen normatif hakim dapat menyisihkan keberlakuan undang- 
undang manakala undang-undang tidak adil (bertentangan dengan prinsip konstitutif hukum yaitu keadilan); "lex iniusta, non est lex".

\section{DAFTAR BACAAN}

\section{Buku}

Alexy, Robert, The Argument from Injustice: A Reply to Legal Positivism (Oxford University Press, 2004).

Altman, Andrew, Arguing About Law (Wadsworth Publishing Co., Belmont-California 2001).

Barak, Aharon, The Judge in a Democracy (Princeton University Press, New Jersey 2006).

Bodenheimer, Edgar, Jurisprudence: The Philosophy and Method of the Law (Harvard University Press 1970).

D'Amato, Anthony, Analytic Jurisprudence Anthology (Anderson Publishing Co., Cincinnati-Ohio 1995).

Dworkin, Ronald, Taking Rights Seriously (Harvard University Press, Cambridge-Massachusetts 1978).

Marmor, Andrei, Law in the Age of Pluralism (Oxford University Press 2007).

McCoubrey, Hilaire, \& Nigel D. White, Textbook on Jurisprudence (Blackstone Press Ltd., London 1996).
Ratnapala, Suri, Jurisprudence (Cambridge University Press 2009).

Thomas, E.W., The Judicial Process: Realism, Pragmatism, Practical Reasoning and Principles (Cambridge University Press 2005).

Waluchow, W.J., Inclusive Legal Positivism (Oxford University Press 1994).

Wilk, Kurt, The Legal Philosophy of Lask, Radbruch and Dabin (Harvard University Press, 1950).

\section{Jurnal}

Fuller, Lon L., 'Positivism and Fidelity to Law-A Reply to Professor Hart' (1958) 71 Harvard Law Review 630.

Hart, H.L.A., 'Positivism and the Separation of Law and Morals' (1958) 71 Harvard Law Review 593.

Leawoods, Heather, 'Gustav Radbruch: An Extraordinary Legal Philosopher' (2000) 2 Washington University Journal of Law and Policy 489.

Leiter, Brian, 'Legal Formalism and Legal Realism: What is the Issue?' (2011) 16 Legal Theory 111.

Lipkin, Robert Justin, 'Conventionalism, Pragmatism and Constitutional Revolutions' (1988) 21 UC Davis Law Review 645.

Singer, Joseph William, 'Normative Methods for Lawyer' (2009) 56 UCLA Law Review 899. 


\section{Bab dalam Buku}

Inoue, Tatsuo, The Rule of Law as the Law of Legislation dalam Luc J. Wintgens ed., Legislation in Context: Essays in Legisprudence (Ashgate, Aldershot-Burlington 2007). 